\title{
Arsenate removal from drinking water using by-products from conventional iron oxyhydroxides production as adsorbents coupled with submerged microfiltration unit
}

\author{
Muhammad Usman $^{1} \cdot$ Ioannis Katsoyiannis ${ }^{2} \cdot$ Josma Henna Rodrigues $^{1} \cdot$ Mathias Ernst $^{1}$
}

Received: 6 January 2020 / Accepted: 4 March 2020 / Published online: 10 April 2020

(C) The Author(s) 2020

\begin{abstract}
Arsenic is among the major drinking water contaminants affecting populations in many countries because it causes serious health problems on long-term exposure. Two low-cost micro-sized iron oxyhydroxide-based adsorbents (which are by-products of the industrial production process of granular adsorbents), namely, micro granular ferric hydroxide ( $\mu \mathrm{GFH})$ and micro tetravalent manganese feroxyhyte ( $\mu \mathrm{TMF}$ ), were applied in batch adsorption kinetic tests and submerged microfiltration membrane adsorption hybrid system (SMAHS) to remove pentavalent arsenic $(\mathrm{As}(\mathrm{V}))$ from modeled drinking water. The adsorbents media were characterized in terms of iron content, BET surface area, pore volume, and particle size. The results of adsorption kinetics show that initial adsorption rate of $\mathrm{As}(\mathrm{V})$ by $\mu \mathrm{TMF}$ is faster than $\mu \mathrm{GFH}$. The SMAHS results revealed that hydraulic residence time of $\mathrm{As}(\mathrm{V})$ in the slurry reactor plays a critical role. At longer residence time, the achieved adsorption capacities at $\mathrm{As}(\mathrm{V})$ permeate concentration of $10 \mu \mathrm{g} / \mathrm{L}$ (WHO guideline value) are 0.95 and $1.04 \mu \mathrm{g} / \mathrm{mg}$ for $\mu \mathrm{GFH}$ and $\mu \mathrm{TMF}$, respectively. At shorter residence time of $\sim 3 \mathrm{~h}, \mu \mathrm{TMF}$ was able to treat 1.4 times more volumes of arsenic-polluted water than $\mu \mathrm{GFH}$ under the optimized experimental conditions due to its fast kinetic behavior. The outcomes of this study confirm that micro-sized iron oyxhydroxides, by-products of conventional adsorbent production processes, can successfully be employed in the proposed hybrid water treatment system to achieve drinking water guideline value for arsenic, without considerable fouling of the porous membrane.
\end{abstract}

Keywords Arsenic removal · Granular ferric hydroxide $\cdot$ Micro-sized iron oxyhydroxides · Waste utilization · Adsorption kinetics $\cdot$ Submerged membrane adsorption hybrid system $\cdot$ Drinking water production

\section{Introduction}

Groundwater is globally the foremost source of drinking water for human consumption. Arsenic contamination of drinking

Responsible Editor: Bingcai Pan

Muhammad Usman

muhammad.usman@tuhh.de

Mathias Ernst

mathias.ernst@tuhh.de

1 Institute for Water Resources and Water Supply, Hamburg University of Technology, Am Schwarzenberg-Campus 3, 20173 Hamburg, Germany

2 Department of Chemistry, Laboratory of Chemical and Environmental Technology, Aristotle University of Thessaloniki, 54124 Thessaloniki, Greece waters across the world is one of the most serious water related problems, because it affects big parts of the global population and it is very harmful to human health. It is well-known that inorganic forms of arsenic are a strong human carcinogen. The World Health Organization (WHO) has set a guideline value of $10 \mu \mathrm{g} / \mathrm{L}$ in drinking water. Both natural and anthropogenic sources contribute to elevated concentrations of arsenic in natural environments (Violante et al. 2006). In groundwaters, arsenic is present mainly with its inorganic forms, arsenite, which is the trivalent form of arsenic [As (III)], and arsenate, which is the pentavalent form of arsenic $[\mathrm{As}(\mathrm{V})]$. More than 150 million inhabitants are under high health risk in more than 70 countries due to pollution of drinking water by arsenic (Abejón and Garea 2015). Therefore, many different attempts such as the use of zero valent iron with main applications in South east Asian countries (Katsoyiannis et al. 2015b) and adsorption of arsenic onto iron oxides and iron oxide-coated 
sand in fixed-bed adsorption filters (Katsoyiannis et al. 2015a; Callegari et al. 2018) are being made to remove it so that people have safe drinking water supplies.

The use of fixed-bed adsorption media filters has gained considerable attention, especially for the treatment of waters with relatively low initial arsenic concentrations (i.e., in the range of 20 to $50 \mu \mathrm{g} / \mathrm{L}$ ) due to the simplicity of operation and the efficiency of arsenic removal. These filters usually use the granular size of the adsorbents, i.e., higher than $250 \mu \mathrm{m}$ (Thirunavukkarasu et al. 2003). However, micro-sized fractions (particle sizes of 1 to $250 \mu \mathrm{m}$ ) of granular ferric hydroxide that are very effective for adsorption of trivalent arsenic (As (III)) and pentavalent arsenic (As(V)) as reported by Usman et al. (2018) cannot be used in fixed-bed filters because of high clogging potential in fixed-bed adsorption filters, rapidly causing an increased pressure head, and thereby increasing energy costs and maintenance (Kalaruban et al. 2018; Vieira et al. 2017). However, considerable amounts of micro-sized fraction of granular ferric hydroxide (GFH), termed $\mu \mathrm{GFH}$ and tetravalent manganese feroxyhyte (TMF), termed $\mu \mathrm{TMF}$ are generated. $\mu \mathrm{GFH}$ is a by-product from industrial production of GFH, while $\mu \mathrm{TMF}$ produced during kilogram-scale production at the laboratory scale. These byproducts might be applied in drinking water production not only to reduce the cost of water treatment, but also supply methods for by-product utilization. If fine fractions of adsorbent media will be added to a fluidized bed reactor, which treats water containing arsenic, adsorption of arsenic will take place. The treated water will subsequently be separated by low-pressure membrane submerged in a reactor. Recently, Hilbrandt et al. (2018) combined embedment of $\mu \mathrm{GFH}$ in a up-flow rapid filter with subsequent particle separator. The objective of particle separator is to retain the particles that might be washed out during the filtration process. However, they have tested the aforementioned process using cylindrical glass columns $(2.4 \times 100 \mathrm{~cm})$ and its scaling up has not yet been performed, since rapid filter closely resemble the fixedbed adsorption filter and fixed-bed filters packed with fine fractions of adsorbents are known to be prone to clogging during the filtration process in waterworks.

In the present study, the use of micro-sized fractions of the proposed adsorbents is investigated and its application is proposed in a combined unit with low-pressure membrane filtration to create an innovative hybrid treatment process, which could reduce the overall costs of treatment by using low-cost adsorbents and create a treatment process easily applicable from the household to the community based level. Low-pressure membrane processes, such as microfiltration (MF) or even ultrafiltration (UF), have a reasonable energy consumption and in general produce excellent hygienic quality treated water with a rather controllable membrane fouling at moderate capital costs (Katsoyiannis et al. 2013). A study of Drouiche et al. (2001) on economic performance of ultrafiltration membrane process indicated that a drinking water system $\left(480 \mathrm{~m}^{3} /\right.$ day $)$ treating surface water in the Kabylia region of Algeria incurred a total cost of $0.235 \$ / \mathrm{m}^{3}$ including capital, energy $\left(0.010 \$ / \mathrm{m}^{3}\right)$, membrane cleaning, and replacement costs.

Recent studies show that the removal of organic and inorganic pollutants from drinking water by a submerged membrane adsorption hybrid system (SMAHS) using micro-sized adsorbents is a promising technology (Vigneswaran et al. 2003; Kalaruban et al. 2018; Hilbrandt et al. 2019). The performance of a SMAHS depends on the adsorption capacity of the applied adsorbent media to remove specific pollutants, mode of adsorbent dosage (initially or continuously dosed to adsorption reactor), adsorption reactor configuration, and operating conditions including water matrix, hydrodynamic conditions such as air bubbling rate, water flux, feed water $\mathrm{pH}$, temperature, etc. (Vigneswaran et al. 2003; Campos et al. 2000; Jia et al. 2009). High membrane water fluxes reduce costs due to large amounts of water being treated by small footprint installations. However, if due to increasing membrane water fluxes the hydraulic retention time in the adsorption reactor is rather short, the pollutant removal efficiency may decrease. Also, high fluxes may increase the rate of fouling on the membrane (critical flux phenomena). Nevertheless, applying aeration to the adsorbent suspension keeps the adsorbent particles completely dispersed in the reactor and helps to reduce the solid deposition on the membrane surface by the air scouring effect (Kalaruban et al. 2018; Stylianou et al. 2018; Choi et al. 2009). For example, in powdered activated carbon (PAC) adsorption-membrane filtration systems, PAC might be initially or continuously dosed into the adsorption reactor. For the "PAC initially dosed" mode, the required PAC is added into the reactor at the start of each filtration cycle. For the "PAC continuously dosed" mode, the PAC is continuously dosed into the adsorption reactor during the filtration cycle. Mathematical modeling using different adsorption kinetic models has shown that higher removal efficiency can be acquired with the "adsorbent initially dosed mode" due to higher adsorbent use efficiency with this approach (Campos et al. 2000; Chang et al. 2003).

The SMAHS and fixed-bed adsorption filters are dynamic and continuous flow treatment systems, which are more relevant to real-water treatment process than the static batch system of water treatment. The advantage of a SMAHS over conventional-bed filters is that micro-sized adsorbents exhibiting high surface area can be used in this system (Kalaruban et al. 2018). Moreover, the micro-sized iron oxyhydroxides are cheaper than the granular fractions. Currently, the costs (on dry basis) for GFH and $\mu \mathrm{GFH}$ materials was estimated to $9 € / \mathrm{kg}$ vs. $1.6 € / \mathrm{kg}$, respectively (Usman et al. 2018). Another synergistic advantage of a SMAHS over fixed-bed absorbers is that low-pressure membranes achieve simultaneous removal of colloids, microorganisms, and suspended solids (Lebeau et al. 1998). 
The primary objective of the study is to exploit the performance of micro-sized porous iron oxyhydroxides and also to identify the low-cost materials suitable for application in SMAHS for $\mathrm{As}(\mathrm{V})$ removal from a model drinking water source at varying operating conditions. The adsorbent efficiency was assessed in terms of volume of treated water until $10 \mu \mathrm{g} \mathrm{As}(\mathrm{V}) / \mathrm{L}$ (EU drinking water directives, US environmental protection agency (EPA) and World Health Organization (WHO) guideline value) was reached as well as the amount of arsenic adsorbed per unit mass of adsorbent. Moreover, the applied adsorbent media was characterized to better understand adsorption behavior. To the best knowledge of the authors, the performance of an adsorption-submerged membrane hybrid system using micro-sized fractions of conventional adsorbents to remove arsenic from drinking water under continuous flow operation is presented for first time in this study.

\section{Material and methods}

$\mu \mathrm{GFH}$ was obtained from $\mathrm{GEH}$ Wasserchemie $\mathrm{GmbH} \&$ Co, Osnabrück, Germany, and TMF was kindly supplied by colleague Manassis Mitrakas from Aristotle University of Thessaloniki (Tresintsi et al. 2013a). $\mu \mathrm{GFH}$ is a byproduct generated during the industrial production of $\mathrm{GFH}$, which is produced from a ferric chloride solution by neutralization and precipitation with sodium hydroxide. The ferric hydroxide precipitate was centrifuged and granulated by a high-pressure process (Thirunavukkarasu et al. 2003), while preparation of TMF involves the coprecipitation of $\mathrm{FeSO}_{4}$ and $\mathrm{KMnO}_{4}$ in a kilogram-scale continuous process. The kilogram-scale production in a laboratory two-stage continuous flow reactor includes the coprecipitation into the water of the iron source $\left(\mathrm{FeSO}_{4}\right.$. $\left.\mathrm{H}_{2} \mathrm{O}\right)$ at $\mathrm{pH} 4$ and the manganese source $\left(\mathrm{KMnO}_{4}\right)$, which is an oxidant for the process and also used to adjust the reaction's redox to $850 \mathrm{mV}$ (Tresintsi et al. 2013a). The generated fraction of $\mu \mathrm{TMF}$ during a laboratory-scale production of TMF was ca. $10 \%$. Therefore, granular TMF $(0.3-2 \mathrm{~mm})$ was grounded to achieve abundant quantity of $\mu \mathrm{TMF}$ to apply in continuous flow experiments. All results were presented on a dry mass basis of both iron oxyhydroxides after drying at $105{ }^{\circ} \mathrm{C}$ for $24 \mathrm{~h}$ and subsequent cooling in a desiccator.

\section{Adsorbent characterization}

Particle size distribution was determined by EyeTech ${ }^{\mathrm{TM}}$ analyzer (Combi, AmbiValue, the Netherlands). The iron content of the adsorptive media was determined by acid digestion. Briefly, $1 \mathrm{~g}$ of media (on dry basis) was added to
$50 \mathrm{~mL}$ of $10 \% \mathrm{HNO}_{3}$ in a glass beaker and the suspension was heated using a hot plate to boiling point. After $2 \mathrm{~h}$, the iron oxide in the suspension was completely dissolved and the acid solution turned yellow (AWWARF 1993)). At this point, heating was ceased, the suspension after cooling was made up to $1 \mathrm{~L}$ with distilled deionized (DI) water, filtered through $0.45-\mu \mathrm{m}$ filter, and the iron content determined by DIN 38406 method using a photometer (model UV-1700, Shimadzu, Germany). The surface area of the media was determined by nitrogen gas adsorption at liquid $\mathrm{N}_{2}$ temperature $(77 \mathrm{~K})$ using a surface area analyzer (Nova 4200, Quantachrome Instruments, USA) according to Brunauere Emmette Teller (BET) model. Six-point surface area measurements were employed to determine the surface area of the samples.

\section{Batch adsorption kinetic procedure}

The kinetics of adsorption was conducted in model ground water (prepared according to National Sanitation Foundation (NSF) standards, termed NSF water hereafter) at $\mathrm{pH} 8 \pm 0.1$ with an adsorbent dose of $100 \mathrm{mg} / \mathrm{L}$ and a As(V) concentration of $190 \mu \mathrm{g} / \mathrm{L}$ by shaking Schott flask (2 L) containing test solution (1 L) at $150 \mathrm{rpm}$ using a platform shaker. NSF water has the following composition: $252 \mathrm{mg} \mathrm{NaHCO}, 12.14 \mathrm{mg} \mathrm{NaNO}_{3}, 0.178 \mathrm{mg} \mathrm{NaH} \mathrm{PO}_{4}$. $\mathrm{H}_{2} \mathrm{O}, 2.21 \mathrm{mg} \mathrm{NaF}, 70.6 \mathrm{mg} \mathrm{NaSiO} \cdot 5 \mathrm{H}_{2} \mathrm{O}, 147 \mathrm{mg} \mathrm{CaCl}{ }_{2}$. $2 \mathrm{H}_{2} \mathrm{O}$, and $128.3 \mathrm{mg} \mathrm{MgSO}_{4} \cdot 7 \mathrm{H}_{2} \mathrm{O}$ in $1 \mathrm{~L}$ of DI water (Simeonidis et al. 2017). The standard solution of $\mathrm{As}(\mathrm{V})$ was $\mathrm{H}_{3} \mathrm{AsO}_{4}$ in $\mathrm{HNO}_{3}(0.05 \mathrm{~mol} / \mathrm{L})$ with a concentration of $1 \mathrm{~g} / \mathrm{L}$. It was obtained from Merck chemical $\mathrm{GmbH}$ (Darmstadt, Germany). The experiments for each adsorbent were performed in duplicate.

Samples were taken at specific time intervals for a period up to $360 \mathrm{~min}$. Upon sampling, samples were filtered with $0.45-\mu \mathrm{m}$ (PES membrane) syringe filters and the filtrates were stored and analyzed at $\mathrm{pH} 2$ using hydrochloric acid for total arsenic. A Perkin-Elmer atomic absorption spectrometer with a Perkin-Elmer Graphite Furnace Tube atomizer was used to measure the arsenic concentrations (Bower 1992). Argon gas was used to atomize the samples. The instrument setup parameters were $380 \mathrm{~mA}$ lamp current, detection at a wavelength of $193.7 \mathrm{~nm}, 0.7 \mathrm{~nm}$ silt width, and peak area as measurement mode.

\section{Submerged membrane adsorption hybrid system}

A self-assembled MF membrane module was made with hollow fiber outside-in PVDF-type membrane (Microza microfilter, Pall membrane) with specifications of $0.1 \mu \mathrm{m}$ nominal pore size and $0.018 \mathrm{~m}^{2}$ was used in a SMAHS to separate the loaded adsorbent particles (Fig. 1). The inner and outer diameter of hollow MF fiber is 0.7 and $1.3 \mathrm{~mm}$, 
Fig. 1 Schematic diagram of the submerged membrane adsorption hybrid system (SMAHS)

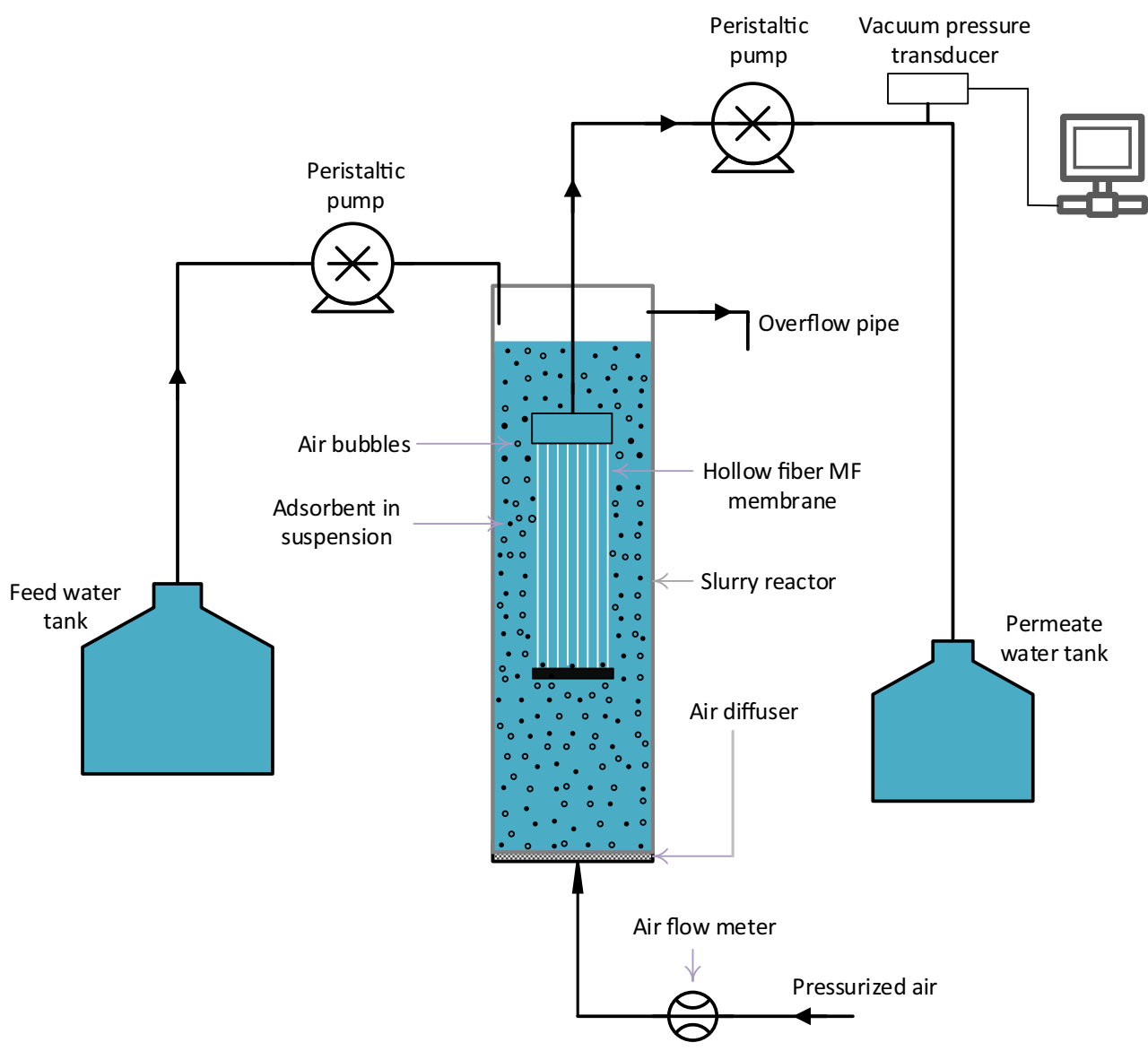

respectively. The feed solution was prepared using NSF water spiked with $\mathrm{As}(\mathrm{V})$ to adjust a concentration of either $190 \mu \mathrm{g} / \mathrm{L}$ or $380 \mu \mathrm{g} / \mathrm{L}$, and the $\mathrm{pH}$ of the solution was maintained at $8 \pm 0.1$.

The SMAHS experiments were carried out in a continuous flow operation. The adsorbents ( $1 \mathrm{~g}$ and $5 \mathrm{~g}$ each) were initially added to $\mathrm{As}(\mathrm{V})$ contaminated NSF water $(1 \mathrm{~L})$ in the slurry reactor and the MF membrane was submerged into the reactor. A peristaltic pump was used to feed the influent water to the slurry reactor and permeate was drawn from the reactor through a second peristaltic pump. The flow rates of both feed and permeate pumps were maintained identical and in order to keep the water level in the reactor constant throughout the experiments. Air was entered continuously from the bottom to keep the adsorbent particles in suspension and to generate scoring on membrane surface. In the absence of air, adsorbent particles could settle at the bottom of the slurry reactor and thus circumventing close contact between adsorbent and As(V) species. The transmembrane pressure was measured by a signal conditioned precision vacuum pressure transducer (423SC15D-PCB, Sensortechnics). The data were collected automatically by a data logger.

In most of studies (Adham et al. 1993; Hashlamon et al. 2017; Qu et al. 2018), the adsorption process is chosen as a pretreatment. However, in this system, the iron oxyhydroxides were added directly to the slurry reactor. Consequently, $\mathrm{As}(\mathrm{V})$ adsorption and separation of arsenic-loaded adsorbent particles by MF membrane take place simultaneously in a single reactor.

\section{Results and discussion}

\section{Characterization of adsorbents}

Table 1 summarizes the physicochemical data derived by own analyses for both applied adsorbents.

As it can be seen in Table 1, both materials present a quite high Fe content and surface area. The results are similar to results of other studies. The determined BET surface area and Fe content of TMF were $187 \mathrm{~m}^{2} / \mathrm{g}$ and $38.1 \mathrm{wt} \%$, respectively (Tresintsi et al. 2013a), while the BET surface area of $\mu \mathrm{GFH}$ reported by Hilbrandt et al. (2018) is $304 \pm 5 \mathrm{~m}^{2} / \mathrm{g}$. Both adsorbents have quite high Fe content, which is important regarding their adsorptive capacity, since the adsorption of arsenic takes place mainly because of the iron-based adsorption sites. In particular the adsorption of $\mathrm{As}(\mathrm{V})$ is believed to be dominated by (monodentate and bidentate) inner-sphere complexation between media surface groups and adsorbing moelcules. These types of surface complexes are restricted 
Table 1 Main physicochemical characteristics of used adsorbent media

\begin{tabular}{llllllll}
\hline Media & $\begin{array}{l}\text { Moisture } \\
\text { content } \\
(\%)\end{array}$ & $\begin{array}{l}\text { Fe } \\
\text { content } \\
(\mathrm{wt} \%)\end{array}$ & $\begin{array}{l}\text { BET } \\
\text { surface } \\
\text { area }\left(\mathrm{m}^{2} / \mathrm{g}\right)\end{array}$ & $\begin{array}{l}\text { Pore } \\
\text { volume } \\
(\mathrm{mL} / \mathrm{g})\end{array}$ & $\begin{array}{l}\text { Mean } \\
\text { particle } \\
\text { size }(\mu \mathrm{m})\end{array}$ & $\begin{array}{l}\text { Surface charge } \\
\text { density }(\mathrm{mmol} \\
\left.\mathrm{OH}^{-} / \mathrm{g}\right)\end{array}$ & $\begin{array}{l}\text { Isoelectric } \\
\text { point (IEP) }\end{array}$ \\
\hline$\mu \mathrm{GFH}$ & $\sim 50 \pm 2$ & 59.8 & $283 \pm 3$ & 0.28 & 78.4 & $0.9^{\mathrm{a}}$ & $7.8 \pm 0.2^{\mathrm{a}}$ \\
$\mu \mathrm{TMF}$ & $\sim 5$ & 44.5 & $178 \pm 8$ & 0.35 & 40.0 & $2.7^{\mathrm{b}}$ & $7.2 \pm 0.1^{\mathrm{c}}$ \\
\hline
\end{tabular}

${ }^{\mathrm{a}}$ Usman et al. (2018), ${ }^{\mathrm{b}}$ Tresintsi et al. (2014b), ${ }^{\mathrm{c}}$ Tresintsi et al. (2013a) to ions such as arsenic that have a high affinity for surface sites and can bind to the media surface through covalent bonding (Essington 2015). The possible ligand exchange reaction for adsorption of $\mathrm{As}(\mathrm{V})$ by iron oxide-based adsorbent may include (Banerjee et al. 2008):

$\mathrm{H}_{2} \mathrm{AsO}_{4}{ }^{-}{ }_{(\mathrm{qq})}+\mathrm{Fe}-\mathrm{OOH}_{(\mathrm{s})} \rightarrow \mathrm{Fe}-\mathrm{H}_{2} \mathrm{AsO}_{4(\mathrm{~s})}+\mathrm{OH}^{-}$

Regarding the surface area of the adsorbents, $\mu \mathrm{GFH}$ has considerably higher BET surface area than $\mu \mathrm{TMF}$. This might play an important role on the adsorption efficiency of arsenic, acting synergistically to the very high Fe content. Both adsorbents have an isoelectric point at values above 7 , in particular at 7.2 for $\mu \mathrm{TMF}$ and 7.8 for $\mu \mathrm{GFH}$. The IEP value of the solid adsorbents plays a critical role as at solution $\mathrm{pH}$ values lower than the IEP, the overall surface charge of the adsorbent is positive. Given the fact that $\mathrm{As}(\mathrm{V})$ species are anionic over a broad $\mathrm{pH}$ range (i.e., from 3 up to 9) $\left(\mathrm{H}_{2} \mathrm{AsO}_{4}{ }^{-}\right.$and $\mathrm{HAsO}_{4}{ }^{2-}$ ), their adsorption onto porous (oxy) hydroxides ( $\mu \mathrm{GFH}$ and $\mu \mathrm{TMF}$ ) takes place mainly via electrostatic (Coulombic interaction) forces as well as ligand exchange reactions (Lewis acid-base interactions) to form monodentate and bidentate inner-sphere complexes (Banerjee et al. 2008). In the present study, the feed solution $\mathrm{pH}$ was much higher than the isoelectric point (IEP), which indicates that Coulombic interaction was not expected to be the main mechanism for $\mathrm{As}(\mathrm{V})$ adsorption and it is adsorbed onto iron oxyhydroxides by the formation of monodentate and bidentate inner-sphere complexes. Generally, it is presumably believed that porous nature of iron (oxy) hydroxides leads to $\mathrm{As}(\mathrm{V})$ adsorption at internal iron complexation sites (Sinha et al. 2002; Badruzzaman et al. 2004).

\section{Effect of contact time}

Batch adsorption kinetics experiments were conducted to study the effect of contact time on the rate of adsorption of $\mathrm{As}(\mathrm{V})$ onto adsorbent media (Fig. 2). The adsorption kinetic plots exhibit that initial rate of $\mathrm{As}(\mathrm{V})$ adsorption onto both adsorbents is rapid and removal rate increases with increasing contact time. At the end of the experiment (contact time of $6 \mathrm{~h})$, about $95 \%$ of the $\mathrm{As}(\mathrm{V})$ was adsorbed onto $\mu \mathrm{TMF}$ relative to $\mu \mathrm{GFH}(93 \%)$. Due to the large concentration gradient between the bulk solution and media surface, the rapid initial removal rate of $\mathrm{As}(\mathrm{V})$ has been observed. This can be seen in Fig. 2 that about $70-80 \%$ of $\mathrm{As}(\mathrm{V})$ was adsorbed within the first $1 \mathrm{~h}$ of contact and only 20-30\% additional As(V) adsorption has occurred in the following $5 \mathrm{~h}$. Banerjee et al. (2008) reported that similar pattern during adsorption of $\mathrm{As}(\mathrm{V})$ onto GFH (with particle sizes between 0.32 and $2 \mathrm{~mm}$ ) in ultrapure deionized water, but at a much higher initial arsenic to media ratio of $0.4 \mu \mathrm{g} \mathrm{As}(\mathrm{V}) / \mathrm{mg}$ GFH. In the present study, initial arsenic to media ratio is $1.9 \mu \mathrm{g} \mathrm{As}(\mathrm{V}) / \mathrm{mg}$. It can be concluded that small size of $\mu \mathrm{GFH}$ favors faster removal rate of $\mathrm{As}(\mathrm{V})$ compared to GFH.

First- and second-order adsorption kinetic models were considered to analyze the removal rates of $\mathrm{As}(\mathrm{V})$ from aqueous solution. The simple forms of the first- and second-order kinetic models can be expressed as follows:

The first-order kinetic model:

$\ln \left(\frac{\mathrm{As}_{\mathrm{t}}}{\mathrm{As}_{\mathrm{o}}}\right)=-k_{1} \mathrm{t}$,

The second-order kinetic model:

$\frac{1}{\mathrm{As}_{\mathrm{t}}}-\frac{1}{\mathrm{As}_{\mathrm{o}}}=k_{2} \mathrm{t}$

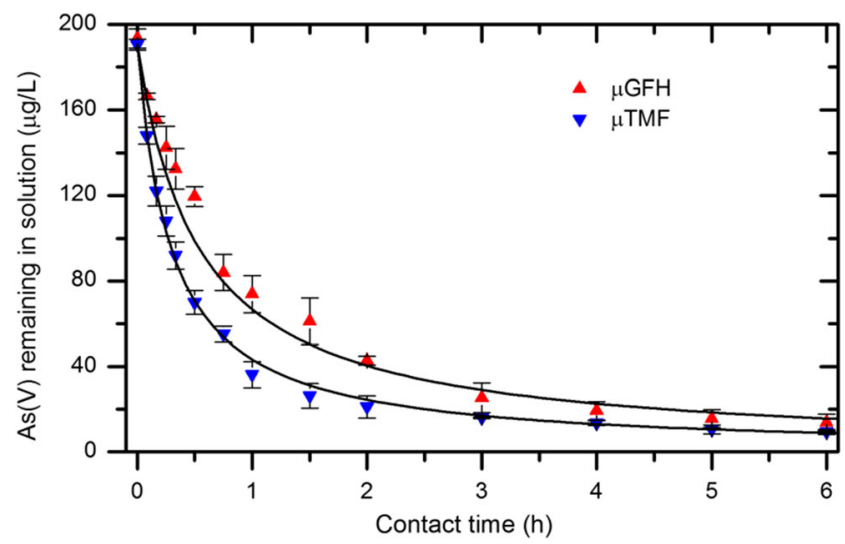

Fig. 2 Effect of contact time on $\mathrm{As}(\mathrm{V})$ adsorption rate onto adsorbents in NSF water $(n=2)$. Solid lines represent the fitting using second-order adsorption kinetic model. Experimental conditions: Adsorbent dosage $=$ $100 \mathrm{mg} / \mathrm{L}$, initial $\mathrm{As}(\mathrm{V})=190 \mu \mathrm{g} / \mathrm{L}, \mathrm{pH}=8 \pm 0.1$ and $\mathrm{T}=20^{\circ} \mathrm{C}$, residual $\mathrm{As}(\mathrm{V})$ concentration for $\mu \mathrm{TMF}$ and $\mu \mathrm{GFH}$ is 9.5 and $13.8 \mu \mathrm{g} / \mathrm{L}$, respectively 
Table 2 The first- and secondorder rate constants $\left(k_{1} \& k_{2}\right)$ for the two adsorbents with different contact times

\begin{tabular}{|c|c|c|c|c|c|c|c|c|}
\hline \multirow[t]{3}{*}{ Media } & \multicolumn{4}{|c|}{ First-order kinetic equation for } & \multicolumn{4}{|c|}{ Second-order kinetic equation for } \\
\hline & \multicolumn{2}{|c|}{ Contact time $(\leq 3 \mathrm{~h})$} & \multicolumn{2}{|c|}{ Contact time $(\leq 6 \mathrm{~h})$} & \multicolumn{2}{|c|}{ Contact time $(\leq 3 \mathrm{~h})$} & \multicolumn{2}{|c|}{ Contact time $(\leq 6 \mathrm{~h})$} \\
\hline & $k_{l}\left(\mathrm{~L} / \mathrm{mg}{ }^{*} \mathrm{~h}\right)$ & $\mathrm{R}^{2}$ & $k_{l}(\mathrm{~L} / \mathrm{mg} * \mathrm{~h})$ & $\mathrm{R}^{2}$ & $k_{2}(\mathrm{~L} / \mathrm{mg} * \mathrm{~h})$ & $\mathrm{R}^{2}$ & $k_{2}(\mathrm{~L} / \mathrm{mg} * \mathrm{~h})$ & $\mathrm{R}^{2}$ \\
\hline$\mu \mathrm{GFH}$ & 1.06 & 0.68 & 0.53 & 0.86 & 0.010 & 0.95 & 0.014 & 0.99 \\
\hline$\mu \mathrm{TMF}$ & 0.74 & 0.95 & 0.65 & 0.50 & 0.020 & 0.99 & 0.018 & 0.99 \\
\hline
\end{tabular}

where $\mathrm{As}_{0}$ is the initial concentration of $\mathrm{As}(\mathrm{V}), \mathrm{As}_{\mathrm{t}}$ is the liquid phase $\mathrm{As}(\mathrm{V})$ concentration remaining in the solution at time $\mathrm{t}$, and $k_{1}$ and $k_{2}$ are rate constants of first- and second-order kinetic models, respectively. The second-order kinetic model shows better fit to the kinetic data of $\mathrm{As}(\mathrm{V})$ adsorption onto iron oxyhydroxides as indicated by the higher correlation coefficient $\left(\mathrm{R}^{2}\right)$ values in Table 2 .

The calculated $k_{2}$ values for the initial contact time of $\leq 3 \mathrm{~h}$ for $\mu \mathrm{TMF}$ and $\mu \mathrm{GFH}$ are 0.02 and $0.01 \mathrm{~L} /\left(\mathrm{mg}^{*} \mathrm{~h}\right)$, respectively (Table 2). The higher value of $k_{2}$ for $\mu \mathrm{TMF}$ indicates the faster adsorption rate. This shows that $\mathrm{As}(\mathrm{V})$ removal occurred more rapidly with the $\mu \mathrm{TMF}$ which has a smaller particle size (Table 1). Though higher As(V) adsorption rate onto $\mu \mathrm{TMF}$ after a contact time of $3 \mathrm{~h}, \mu \mathrm{TMF}$ removes $22 \%$ more arsenic within this time compared to $\mu \mathrm{GFH}$.

\section{As(V) removal using submerged membrane adsorption hybrid system}

The influence of various operating conditions on slurry reactor combining adsorption onto adsorbent media and a submerged MF membrane has been studied. In this unit, the added adsorbent media is used to remove pollutants, e.g., As(V) which is present in the source water, and at a second step, the submerged membrane functions as a complete barrier to arsenic loaded media particles. In the following section, the influence of several operational parameters have been studied, in order to define the optimum conditions for efficient operation of the hybrid treatment system.

\section{Hydrodynamic conditions/influence of air bubbling rate}

The influence of bubbling on the adsorption process has been studied at bubbling rates $1.25,2$, and $3 \mathrm{~L}_{\text {air }} /\left(\min\right.$. $\left.\mathrm{L}_{\text {slurry }}\right)$. Air was transported from an air cylinder by PVC tubing to a sintered glass diffuser to generate fine air bubbles.

The adsorption process normally follows four consecutive steps (Jia et al. 2009): (1) external diffusion from bulk solution to liquid film, (2) diffusion in the liquid film surrounding the particle surface, (3) surface diffusion along the adsorbent inner surface, (4) adsorption of pollutant onto the active sites in the micropores. Among these four steps, the air bubbling rate will have an effect on the first two steps. Jia et al. (2009) reported during adsorption of Atrazine on PAC that mass transfer in the liquid film surrounding the adsorbent particle is very sensitive to air bubbling rate, and therefore, optimum air bubbling rate should be achieved for better removal of pollutant via adsorption in SMAHS.

Figure 3 shows that at all three air bubbling rates, As(V) removal efficiency of about $80 \%$ was achieved after approximately $5 \mathrm{~min}$. At air bubbling rates of 2 and $3 \mathrm{~L} / \mathrm{min}$, an increase in the $\mathrm{As}(\mathrm{V})$ concentration with time was slow and As $(V)$ removal efficiency of over $70 \%$ was achieved in a $6 \mathrm{~h}$ long continuous flow experiment. However, in case of $1.25 \mathrm{~L} /$ min, the increase in $\mathrm{As}(\mathrm{V})$ concentration with time was comparatively faster than that of 2 and $3 \mathrm{~L} / \mathrm{min}$, and at the end of $6 \mathrm{~h}$, the $\mathrm{As}(\mathrm{V})$ permeate concentration was approximately $70 \mu \mathrm{g} / \mathrm{L}$ (just over $60 \%$ removal efficiency) at air bubbling rate of $1.25 \mathrm{~L} / \mathrm{min}$, while at $2 \mathrm{~L} / \mathrm{min}$, the $\mathrm{As}(\mathrm{V})$ permeate concentration was around 1.5 times lower than that of at $1.25 \mathrm{~L} / \mathrm{min}$ air bubbling rate. It is concluded that air bubbling rate affects the arsenic concentration profile over time and reveals positive effect on adsorption process with increasing air bubbling rate from 1.25 to $2 \mathrm{~L} / \mathrm{min}$. Further increase in bubbling to $3 \mathrm{~L} / \mathrm{min}$ did not noticeably enhance $\mathrm{As}(\mathrm{V})$ adsorption rate. According to Jia et al. (2005), there is a limit to

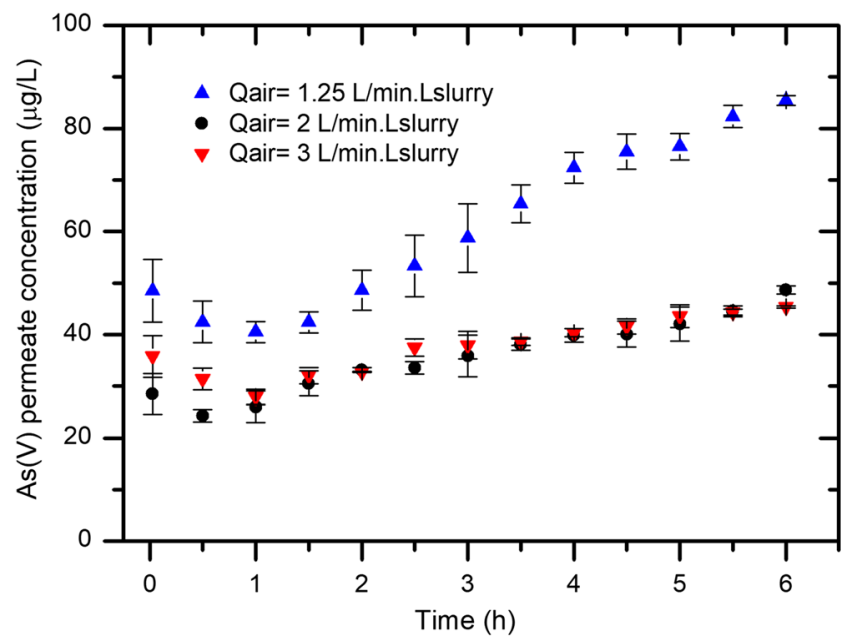

Fig. $3 \mathrm{As}(\mathrm{V})$ concentration in the permeate water over time in a SMAHS with $\mu \mathrm{GFH}$ for varying air bubbling rates with $\mathrm{As}(\mathrm{V})=190 \mu \mathrm{g} / \mathrm{L}$, adsorbent dosage $=1 \mathrm{~g} / \mathrm{L}$, membrane flux $=20 \mathrm{~L} /\left(\mathrm{m}^{2} . \mathrm{h}\right)$, feed solution $\mathrm{pH}=8.0$ and permeate $\mathrm{pH}=8.0-8.2$ 
bubble-induced mass transfer. This indicates that hydrodynamic conditions at $\geq 2 \mathrm{~L}_{\mathrm{air}} / \mathrm{min}$ for $\mathrm{As}(\mathrm{V})$ mass transfer are optimized and a further increase in air bubbling rate will not promote the adsorption rate. It can also be concluded that air bubbles produced by means of sintered glass diffuser keep the adsorbent in suspension, therefore promotes the contact between adsorbent and adsorbate.

\section{Influence of adsorbent dosage}

Once the effect of the air inflow rate was quantified, the next important parameter in continuous operation units is the adsorbent dosage. In this section, the evaluation of the adsorption media in SMAHS was studied in terms of its ability to decrease the $\mathrm{As}(\mathrm{V})$ permeate concentration below the drinking water guideline value of $10 \mu \mathrm{g} / \mathrm{L}$ (termed $\mathrm{Q}_{10, \text { SMAHS }}$ hereafter), rather than to enhance the maximum capacity $\left(\mathrm{Q}_{\max }\right)$ and/ or higher removal efficiencies, which provides marginal information on ability of a specific adsorbent to reach guideline value set by EU drinking water directives, US environmental protection agency (EPA), and the World Health Organization (WHO). At an adsorbent dosage of $1 \mathrm{~g} / \mathrm{L}$, over $80 \% \mathrm{As}(\mathrm{V})$ removal efficiency was obtained but $\mathrm{As}(\mathrm{V})$ concentration in the permeate exceeded the desire $10 \mu \mathrm{g} / \mathrm{L}$ WHO guideline value. Therefore, the amount of adsorbent initially dosed into the slurry reactor was increased to $5 \mathrm{~g} / \mathrm{L}$ from $1 \mathrm{~g} / \mathrm{L}$ to guarantee the $\mathrm{As}(\mathrm{V})$ permeate concentration below the WHO guideline value of $10 \mu \mathrm{g} / \mathrm{L}$ (Fig. 4).

It is pertinent to mention that by increasing the adsorbent dosage a slight increase to the $\mathrm{pH}$ value of the permeate (ranging between 8.0 and 8.3) was observed which can be attributed to the release of hydroxyl ion during adsorption of $\mathrm{As}(\mathrm{V})$ onto hydrous iron oxyhydroxide-based adsorbent (Eq. 1).

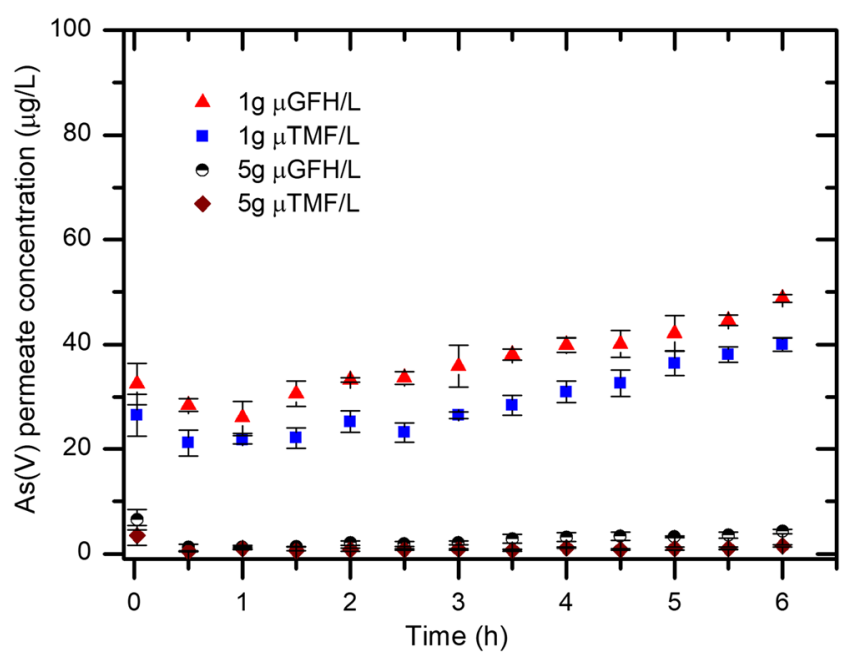

Fig. $4 \mathrm{As}(\mathrm{V})$ concentration in permeate over time in a SMAHS with $\mu \mathrm{GFH}$ and $\mu \mathrm{TMF}$ for adsorbent dosages of 1 and $5 \mathrm{~g} / \mathrm{L}$ with initial $\mathrm{As}(\mathrm{V})$ concentration of $190 \mu \mathrm{g} / \mathrm{L}$, air bubbling rate $=2 \mathrm{~L} / \mathrm{min}$ and permeate $\mathrm{pH}=8.0-8.3$
While at the dosage of $1 \mathrm{~g} / \mathrm{L}$ of adsorbent initially dosed to the reactor, a slight difference in the $\mathrm{As}(\mathrm{V})$ adsorption efficiency between the two adsorbents was observed, at the dosage of $5 \mathrm{~g} / \mathrm{L}$, both adsorbent removed almost completely arsenic, and final concentrations were very low even up to the end of the experiment, i.e., after $6 \mathrm{~h}$. Furthermore, at the dosage of $1 \mathrm{~g} / \mathrm{L}$, there is a continuous increase in the As(V) permeate concentration with time which starts to be evident even from the first hour of the experiment, most likely because of the gradual exhaustion of the adsorbent sites. In the case of $5 \mathrm{~g} / \mathrm{L}$, only after $4 \mathrm{~h}$ of the experiment, a slight increase in the permeate concentrations starts to be detected, but in all measurements, the $\mathrm{As}(\mathrm{V})$ permeate concentration was below the $10 \mu \mathrm{g} / \mathrm{L}$.

However, it was found in this work that at an adsorbent dosage of $1 \mathrm{~g} / \mathrm{L}$, both adsorbents failed to meet the guideline value of $10 \mu \mathrm{g} / \mathrm{L}$ for arsenic in drinking water, as indicated at the EU Directive 98/83/EC. In the first case, the dosed adsorbent corresponds to $0.19 \mathrm{mg} \mathrm{As}(\mathrm{V}) / \mathrm{g}$ of adsorbent while in the second case, the ratio is 5 times lower, thus equals to $3.8 \times$ $10^{-2} \mathrm{mg} \mathrm{As}(\mathrm{V}) / \mathrm{g}$ Adsorbent, under optimized conditions of air bubbling. During removal of nitrate in a submerged membrane adsorption system using ion exchange resins at water flux of $15 \mathrm{LMH}$, Kalaruban et al. (2018) used a ratio of $8 \mathrm{mg}$ $\mathrm{NO}_{3} / \mathrm{g}$ to lower the adsorbate concentration from $20 \mathrm{mg} / \mathrm{L}$ to less than $11.3 \mathrm{mg} / \mathrm{L}$ (roughly $7 \mathrm{mg} / \mathrm{L}$ ) in the reactor or permeate concentration, which is the guideline value for nitrate. Under these conditions, both adsorbent failed to maintain the nitration permeate concentration below $11.3 \mathrm{mg} / \mathrm{L}$ after $3-4 \mathrm{~h}$ at a hydraulic retention time of $2.7 \mathrm{~h}$ in the reactor.

\section{Influence of hydraulic residence time}

The residence time is a limiting factor in the slurry reactor as the adsorption kinetic plot (Fig. 2) shows that $\mathrm{As}(\mathrm{V})$ removal rate

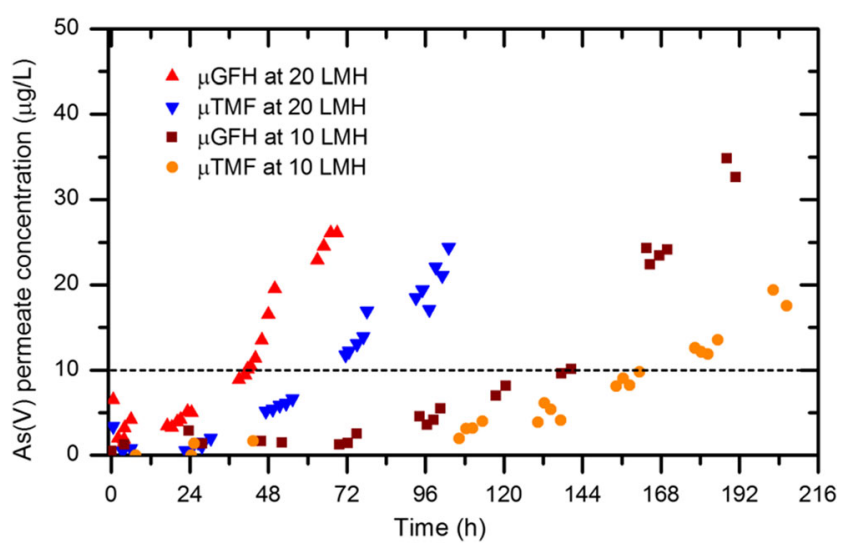

Fig. $5 \mathrm{As}(\mathrm{V})$ concentration in permeate vs. time for both media in a SMAHS at two different hydraulic residence times for adsorbent dosages of $5 \mathrm{~g} / \mathrm{L}$ with initial $\mathrm{As}(\mathrm{V})$ concentration of $190 \mu \mathrm{g} / \mathrm{L}$, air bubbling rate $=2 \mathrm{~L} / \mathrm{min}$ and permeate $\mathrm{pH}=8.0-8.3$. The dashed line indicates the $\mathrm{WHO}$ guideline value for arsenic in drinking water 
increased with increasing contact time. Therefore, the influence of hydraulic residence time on the performance of SMAHS has been studied at water fluxes of $10 \mathrm{~L} /\left(\mathrm{m}^{2} \mathrm{~h}\right)$ and $20 \mathrm{~L} /\left(\mathrm{m}^{2} \mathrm{~h}\right)$. Because the hydraulic retention times of $\mathrm{As}(\mathrm{V})$ in the slurry reactor were $2.8 \mathrm{~h}$ and $5.6 \mathrm{~h}$ at $20 \mathrm{~L} /\left(\mathrm{m}^{2} \mathrm{~h}\right)$ and $10 \mathrm{~L} /\left(\mathrm{m}^{2} \mathrm{~h}\right)$, respectively, accordingly, the initial $3 \mathrm{~h}$ and $6 \mathrm{~h}$ contact times of $\mathrm{As}(\mathrm{V})$ with media in adsorption kinetics were considered. Figure 5 shows the As(V) permeate concentration profiles derived by monitoring the SMAHS experiments using microsized iron oxyhydroxides. The results show that the addition of adsorbent results in a sudden decrease in As $(\mathrm{V})$ concentration from $190 \mu \mathrm{g} / \mathrm{L}$ to a minimum value in the slurry reactor and after a day the $\mathrm{As}(\mathrm{V})$ concentration starts to increase with time. However, for the $10 \mathrm{LMH}, \mathrm{As}(\mathrm{V})$ concentration in the reactor stayed at minimum value for 3 days, and after which, the $\mathrm{As}(\mathrm{V})$ concentration in the permeate starts to rise but at a slower rate than $20 \mathrm{LMH}$.

It can be seen in Fig. 5 that $\mathrm{As}(\mathrm{V})$ permeate concentration profiles over time for both media in hybrid system are effected by the membrane water fluxes. However, the increase in $\mathrm{As}(\mathrm{V})$ permeate concentration over time for $\mu \mathrm{GFH}$ was rapid at both water fluxes. This shows that the $\mu \mathrm{TMF}$ is more effective than $\mu \mathrm{GFH}$ in adsorbing $\mathrm{As}(\mathrm{V})$ in the presence of competing ions.

The performance of media has been assessed in terms of the amount of $\mathrm{As}(\mathrm{V})$ adsorbed per unit mass of adsorbent and volume of treated water up to a guideline value of $10 \mu \mathrm{g} / \mathrm{L}$. $\mathrm{Q}_{10}$, smaHs was calculated by dividing the area above the $\mathrm{As}(\mathrm{V})$ concentration curves by the initially added dry mass of adsorbent.

It can be seen from Fig. 6 that higher residence time (or lower flux of $10 \mathrm{LMH}$ ) increases the adsorption efficiency of media in removing $\mathrm{As}(\mathrm{V})$ from modeled groundwater, and thus is favorable, although it produces less treated water per unit time. The amount of $\mathrm{As}(\mathrm{V})$ adsorbed per unit mass of media has been decreased at 20 LMH. At 20 $\mathrm{LMH}$, the recorded adsorption capacity of $\mu \mathrm{GFH}$ is $36.2 \%$ less than that of $\mu \mathrm{TMF}$. The difference decreases to $9.9 \%$ at $10 \mathrm{LMH}$. This difference in $\mathrm{Q}_{10 \text {,SMAHs }}$ at lower contact times can be explained by lower $k_{2}$ values of $\mu$ GFH (Table 2). These results showed that although the kinetics of $\mathrm{As}(\mathrm{V})$ adsorption was much faster for $\mu \mathrm{TMF}$, the amount of arsenic adsorbed was finally similar for both adsorbent, and therefore, when the flux was decreased, the difference in arsenic capacity of both adsorbents-before As(V) permeate concentration reaches the $10 \mu \mathrm{g} / \mathrm{L}$ - has been reduced. This difference in $\mathrm{Q}_{10 \text {,SMAHs value might }}$ also be due to greater surface charge density of $\mu \mathrm{TMF}$ (2.7 $\mathrm{mmol} \mathrm{OH}^{-} / \mathrm{g}$ ) than $\mu \mathrm{GFH}\left(0.89 \mathrm{mmol} \mathrm{OH}^{-} / \mathrm{g}\right)$. It is concluded that either particle size or surface charge characteristics or both have significant influence on practical adsorption capacity $\left(\mathrm{Q}_{10, \mathrm{SMAHS}}\right)$ for drinking water production observed in SMAHS, even though $\mu \mathrm{GFH}$ has higher BET surface area and IEP than $\mu \mathrm{TMF}$.

The volume of water treated by unit mass of adsorbent to reach $\mathrm{As}(\mathrm{V})$ permeate concentration of $10 \mu \mathrm{g} / \mathrm{L}$ was calculated by defining as specific system productivity (SSP):

$\mathrm{SSP}=\frac{\mathrm{Q}_{10}}{\mathrm{~V} \mathrm{M}_{\mathrm{ad}}}$

Where $\mathrm{Q}$ is the volumetric flow rate at corresponding membrane water flux, $\mathrm{T}_{10}$ is time taken to reach $10 \mu \mathrm{g} \mathrm{As}(\mathrm{V}) / \mathrm{L}$ concentration in permeate, $\mathrm{V}$ is the liquid volume in the reactor, and $\mathrm{M}_{\mathrm{ad}}$ is the mass of adsorbent initially dosed into the reactor. The results revealed (Fig. 6b) that the system productivity is higher at lower membrane water flux and vice versa. Furthermore, the recorded system productivity using $\mu \mathrm{TMF}$ is higher, compared with $\mu \mathrm{GFH}$ at both water fluxes. Figure 7 shows transmembrane pressure profile for constant flux
Fig. 6 a Adsorption efficiency of both media in a SMAHS. $\mathbf{b}$ Specific system productivity at initial $\mathrm{As}(\mathrm{V})=190 \mu \mathrm{g} / \mathrm{L}$ and permeate $\mathrm{pH}=8.0-8.3$
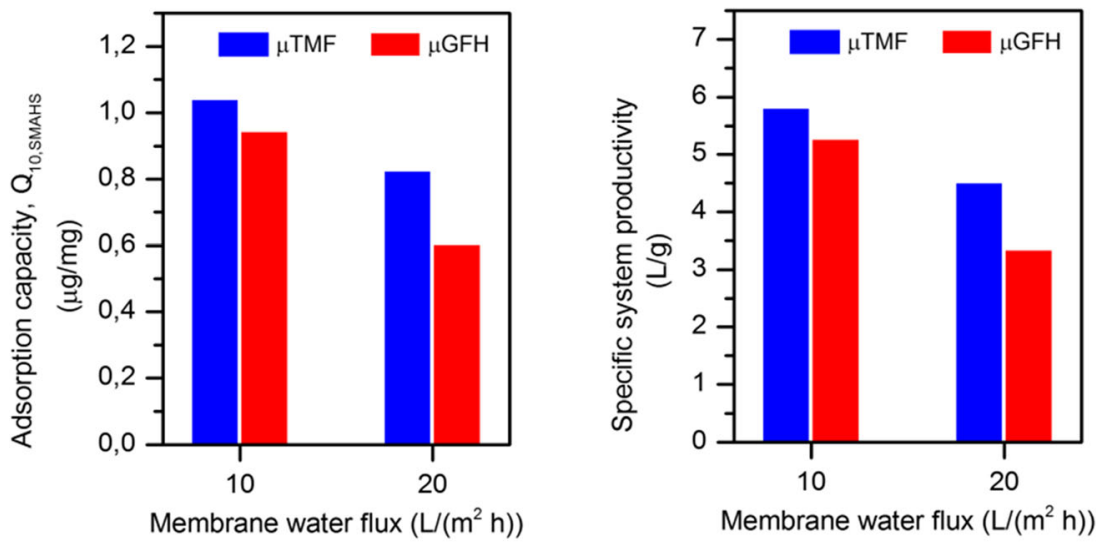

(a) (b) 


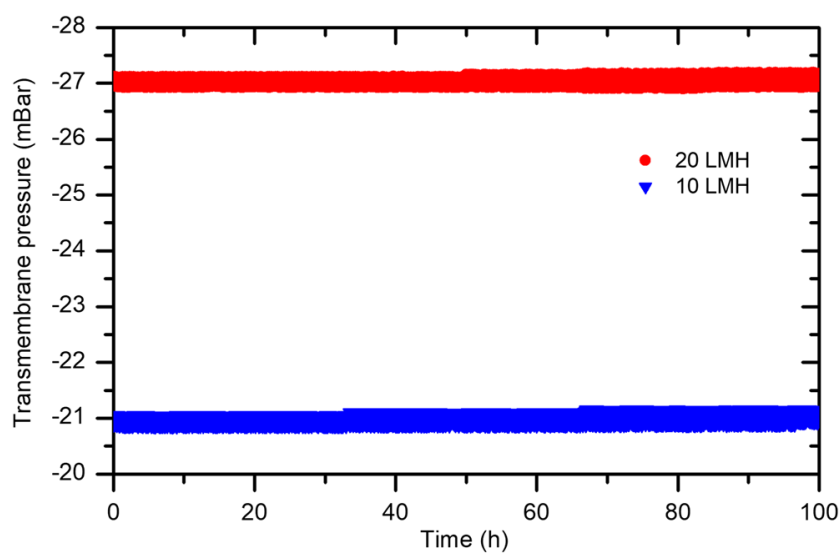

Fig. 7 Transmembrane pressure profile during constant water flux in a submerged membrane adsorption hybrid system

filtration of 10 and $20 \mathrm{LMH}$. On the whole, it can be seen that the no fouling occurred during operation for both applied fluxes. It is recommended that membrane fouling behavior must be considered for long-term operation.

In summary, the As(V) adsorption capacity in SMAHS at contact time $\leq 6 \mathrm{~h}$ using $\mu \mathrm{TMF}$ is higher compared to $\mu \mathrm{GFH}$ at two different water fluxes. In a former study, we determined adsorption capacity $\left(\mathrm{Q}_{10, \text { batch }}\right)$ through batch adsorption isotherm studies of $3.2 \mu \mathrm{g} \mathrm{As}(\mathrm{V}) / \mathrm{mg}$ and $3.3 \mu \mathrm{g} \mathrm{As}(\mathrm{V}) / \mathrm{mg}$ in NSF water for $\mu \mathrm{GFH}$ and at an equilibrium liquid phase concentration of $10 \mu \mathrm{g} / \mathrm{L}$ and at same $\mathrm{pH}$ with much longer contact time until adsorption equlibrium was reached (Usman et al. 2018). In batch adsorption tests, the recorded adsorption capacity of $\mu \mathrm{TMF}$ was $3.1 \%$ higher than $\mu \mathrm{GFH}$. However, the obtained $\mathrm{Q}_{10}$ value for $\mu \mathrm{TMF}$ in SMAHS is $9.5 \%$ higher than the respective $Q_{10}$ value for $\mu \mathrm{GFH}$; this might be attributed to smaller particle size of $\mu \mathrm{TMF}$, due to which adsorption rate is rapid as indicated by the adsorption kinetic plot of $\mu \mathrm{TMF}$.

\section{Influence of initial $\mathrm{As}(\mathrm{V})$ concentration}

The volume of water treated and amount of $\mathrm{As}(\mathrm{V})$ adsorbed per unit mass of adsorbent in the SMAHS using both adsorbents at varying $\mathrm{As}(\mathrm{V})$ feed concentrations and at identical flux is listed in Table 3.
As anticipated, specific system productivity using the micro-sized ion oxyhydroxides has been declined, when the $\mathrm{As}(\mathrm{V})$ feed concentration was increased from 190 to $380 \mu \mathrm{g} / \mathrm{L}$. A reduction of $6 \%$ and $10 \%$ are recorded for $\mu \mathrm{GFH}$ and $\mu \mathrm{TMF}$, respectively. However, $\mathrm{Q}_{10 \text {,SMAHs value }}$ has been increased at the same water flux for both iron oxyhydroxides since the amount of arsenic entering the slurry reactor per unit time has been increased, and subsequently, the concentration gradient between the adsorbate in solution and the media solid surface has been increased and lead to higher $\mathrm{Q}_{10}$ value of both adsorbents. The time taken to reach the $\mathrm{As}(\mathrm{V})$ permeate concentration of $10 \mu \mathrm{g} / \mathrm{L}$ has been decreased in case of higher initial As(V) concentration of $380 \mu \mathrm{g} / \mathrm{L}$. Hilbrandt et al. (2019) reported that during adsorption of phosphate onto $\mu \mathrm{GFH}$ in an adsorption-membrane hybrid system that a sharp slope of the breakthrough curve is favorable as it indicates less influence of film diffusion on adsorption. Due to which, a sharp increase in $\mathrm{As}(\mathrm{V})$ permeate concentration was observed and target contaminant concentration of $10 \mu \mathrm{g} / \mathrm{L}$ in the treated permeate with $\mathrm{As}(\mathrm{V})$ feed concentration of $380 \mu \mathrm{g} / \mathrm{L}$ was accomplished earlier than with $190 \mu \mathrm{g} \mathrm{As}(\mathrm{V}) /$ L.

\section{Comparison of As(V) removal efficiency using SMAHS and fixed-bed filtration filter}

The performance of the SMAHS using micro-sized iron hydroxides can be compared with laboratory- and full-scale fixed-bed adsorbers used for As(V) removal from the water via adsorption onto granular fractions of iron oxyhydroxidebased adsorbents as well as iron oxide-coated sand (Table 4). Tresintsi et al. (2013b) obtained higher $\mathrm{As}(\mathrm{V})$ adsorption capacity (i.e., $\mathrm{Q}_{10}$ value) of $\mathrm{GFH}$, with particle size ranging between 250 and $500 \mu \mathrm{m}$, in rapid small-scale column test (RSSCT) than that of SMAHS using $\mu \mathrm{GFH}$ (1.7 vs. $0.95 \mu \mathrm{g} / \mathrm{mg}$ at $10 \mathrm{LMH}$ or $0.61 \mu \mathrm{g} / \mathrm{mg}$ at $20 \mathrm{LMH})$. This difference in adsorption capacity might be explained because the two studies were conducted under different experimental setups and conditions, since the actual adsorption capacity of an adsorbent for a specific pollutant depends on experimental setups, water matrix, and solution $\mathrm{pH}$.
Table 3 Volume of water treated and $\mathrm{Q}_{10, \mathrm{SmAHs}}$ value for $\mathrm{As}(\mathrm{V})$ concentration $<10 \mu \mathrm{g} / \mathrm{L}$ for two adsorbent media at varying $\mathrm{As}(\mathrm{V})$ feed concentrations with adsorbent dosage $=5 \mathrm{~g} / \mathrm{L}$, water flux $=20 \mathrm{LMH}, \mathrm{pH}=8 \pm 0.1$ and air bubbling rate $=2 \mathrm{~L} / \mathrm{min}$. $\mathrm{L}_{\text {slurry }}$

\begin{tabular}{llllllll}
\hline Media & $\begin{array}{l}\text { Influent } \\
\text { As(V) conc. } \\
(\mu \mathrm{g} / \mathrm{L})\end{array}$ & $\begin{array}{l}\text { Total } \\
\text { operation } \\
\text { time }(\mathrm{h})\end{array}$ & $\begin{array}{l}\text { Total } \\
\text { volume } \\
\text { filtrated }(\mathrm{L})\end{array}$ & $\begin{array}{l}\mathrm{T}_{10} \\
(\mathrm{~h})\end{array}$ & $\begin{array}{l}\text { Amount of } \\
\text { As(V) adsorbed } \\
(\mathrm{mg})\end{array}$ & $\begin{array}{l}\text { SSP } \\
(\mathrm{L} / \mathrm{g})^{\mathrm{a}}\end{array}$ & $\begin{array}{l}\mathrm{Q}_{10, \mathrm{SMAHS}} \\
(\mu \mathrm{g} / \mathrm{mg})\end{array}$ \\
\hline$\mu \mathrm{GFH}$ & 190 & 69 & 24.9 & 45.8 & 3.0 & 3.3 & 0.61 \\
& 380 & 68 & 27.5 & 43.0 & 5.8 & 3.1 & 1.15 \\
$\mu \mathrm{TMF}$ & 190 & 103 & 37.1 & 64.1 & 4.1 & 4.6 & 0.82 \\
& 380 & 102 & 36.6 & 57.0 & 7.7 & 4.1 & 1.54 \\
\hline
\end{tabular}

${ }^{\text {a }}$ When $\mathrm{As}(\mathrm{V})$ concentration in permeate reached the WHO guideline value of $10 \mu \mathrm{g} / \mathrm{L}$ 
Table 4 As(V) adsorption capacity of different iron oxyhydroxide-based adsorbents in a fixed-bed adsorption filter and SMAHS

\begin{tabular}{|c|c|c|c|c|c|c|c|}
\hline Type of system & Test solution & $\mathrm{pH}$ & $\begin{array}{l}\text { Phosphate } \\
\text { conc. }(\mathrm{mg} / \mathrm{L})\end{array}$ & $\begin{array}{l}\text { Silica conc. } \\
(\mathrm{mg} / \mathrm{L})\end{array}$ & $\begin{array}{l}\text { Influent } \\
\text { As }(\mathrm{V}) \text { conc. }\end{array}$ & $\begin{array}{l}\mathrm{Q}_{10} \\
(\mu \mathrm{g} / \mathrm{mg})\end{array}$ & Reference \\
\hline GFH packed fixed-bed adsorber & Mitrousi (Greece) tap water & 7.3 & 0.6 & 14 & 19 & 1.6 & \multirow{2}{*}{$\begin{array}{l}\text { (Tresintsi } \\
\quad \text { et al. 2013b) }\end{array}$} \\
\hline GFH packed RSSCT (lab-scale) & $\begin{array}{l}\text { Thessaloniki (Greece) tap } \\
\text { water }\end{array}$ & 7.9 & 0.3 & 20 & 100 & 1.7 & \\
\hline GFH packed RSSCT (lab-scale) & Arizona (USA) groundwater & 7.6 & - & 34 & 14 & 0.75 & \multirow{2}{*}{$\begin{array}{l}\text { Westerhoff } \\
\text { et al. (2005) }\end{array}$} \\
\hline GFH packed fixed-bed adsorber & Arizona (USA) groundwater & 7.8 & - & 39 & 34 & 1.6 & \\
\hline SMAHS using $\mu \mathrm{GFH}$ at $20 \mathrm{LMH}$ & Artificial groundwater & 8 & 0.12 & 20 & 190 & 0.61 & \multirow[t]{4}{*}{ This work } \\
\hline & & 8 & 0.12 & 20 & 380 & 1.15 & \\
\hline \multirow[t]{2}{*}{ SMAHS using $\mu \mathrm{TMF}$ at $20 \mathrm{LMH}$} & \multirow[t]{2}{*}{ Artificial groundwater } & 8 & 0.12 & 20 & 190 & 0.82 & \\
\hline & & 8 & 0.12 & 20 & 380 & 1.54 & \\
\hline $\begin{array}{l}\text { Iron oxide-coated sand } \\
\text { packed fixed-bed adsorber }\end{array}$ & Groundwater & 7.6 & - & - & 1000 & 0.002 & $\begin{array}{l}\text { Callegari } \\
\text { et al. (2018) }\end{array}$ \\
\hline $\begin{array}{l}\text { Amyloid fibril - carbon hybrid mem- } \\
\text { branes }\end{array}$ & Ultrapure water & 7 & - & - & 239 & 0.27 & $\begin{array}{l}\text { Bolisetty et al. } \\
\qquad(2017)\end{array}$ \\
\hline
\end{tabular}

Better performance of RSSCT packed with granular ironoxyhydroxides for $\mathrm{As}(\mathrm{V})$ is associated to a larger concentration gradient between the adsorbate in solution and the media solid surface. The adsorbent in RSSCT is always in contact with the influent arsenic concentration, which results in a higher driving force over the whole adsorption process. However, in a SMAHS, the influent arsenic concentration is in contact with slurry, which has very low liquid phase arsenic concentration especially at the start of adsorption process when all adsorption sites are empty and arsenic removal occurred very rapidly, due to which the mass transfer driving force (concentration gradient) is very low compared to RSSCT. This is becoming more obvious, when the initial arsenic concentration increased to $380 \mu \mathrm{g} / \mathrm{L}$. This provided more contact of arsenic species with the slurry of iron oxides and caused an increase in $\mathrm{Q}_{10, \mathrm{SMAHS}}$ from 0.82 to 1.54 for $\mu \mathrm{TMF}$ and from 0.61 to 1.15 for $\mu \mathrm{GFH}$ respectively.

Regarding the experimental conditions, As $(\mathrm{V})$ removal from the water via adsorption onto iron oxyhydroxides is known to be impacted by solution $\mathrm{pH}$ and presence of competing ions in the drinking water matrix. Westerhoff et al. (2005) investigated the arsenic adsorption in RSSCT packed with GFH using a different drinking water matrix with an $\mathrm{As}(\mathrm{V})$ influent concentration of $14 \mu \mathrm{g} / \mathrm{L}$ - where the concentration driving force might be in the same range as in SHAHS - even though the obtained $\mathrm{Q}_{10}$ value in RSSCT packed with GFH is lower than that of SMAHS using $\mu \mathrm{GFH}$. This is possible because the both studies were conducted in a different drinking water matrix. A study by Amy et al. (2005) on effect of water matrix on arsenic adsorption reported a reduction of $70 \%$ in $\mathrm{As}(\mathrm{V})$ adsorption capacity onto GFH in the presence of $13.5 \mathrm{mg} / \mathrm{L}$ silica $\left(\mathrm{SiO}_{2}\right)$ at $\mathrm{pH} 8 \mathrm{in}$ batch adsorption tests. Similarly, $75 \%$ reduction in $\mathrm{As}(\mathrm{V})$ adsorption capacity was recorded in presence of $250 \mu \mathrm{g} / \mathrm{L} \mathrm{PO}_{4}{ }^{3-}$ under similar experimental conditions.
Concerning the $\mathrm{pH}$ value, most commonly used adsorbents adsorb arsenic more effectively at $\mathrm{pH}$ values below IEP and their adsorptive capacities increase with decreasing $\mathrm{pH}$ (Tresintsi et al. 2012). During adsorption of $\mathrm{As}(\mathrm{V})$ onto iron oxyhydroxides, synthesized in laboratory at kilogram scale, in RSSCT, the $\mathrm{Q}_{10}$ value was increased from 2.8 to 6.8 to $10.7 \mu \mathrm{g} / \mathrm{mg}$ at 8,7 , and 6 , respectively. This study demonstrated that by decreasing the solution $\mathrm{pH}$ by one unit from 8 to 7 , the adsorption efficiency of adsorbent increased by 2.4 times. Similar results were obtained by Katsoyiannis and Zouboulis (2002), where $\mathrm{As}(\mathrm{V})$ adsorption was studied in fixed-bed columns using amorphous iron oxides as adsorbent; the bed volumes treated before arsenic concentration reached the $10 \mu \mathrm{g} / \mathrm{L}$ were increased as the $\mathrm{pH}$ decreased from 9 to 7 . This is because as the $\mathrm{pH}$ decreases, the surface charge of the adsorbent becomes more positive and favors the adsorption of oxyanion species on their surface.

In summary, this difference in adsorption capacity between two studies could be attributed to water matrix as well as solution $\mathrm{pH}$ in addition to $\mathrm{As}(\mathrm{V})$ influent concentration, and therefore, it is relevant to mention that these factors play pivotal role while comparing the removal efficiencies of two water treatments systems for $\mathrm{As}(\mathrm{V})$ at roughly the same concentration driving force. From the above discussion, it is concluded that the removal efficiencies of both treatment systems are comparable for $\mathrm{As}(\mathrm{V})$ especially when the concentration driving force is higher in the slurry reactor and also taking into account the effect of the water matrix and solution $\mathrm{pH}$. In one system, adsorbent media is fixed, while in hybrid system, adsorbent media is in suspension. Takin into account the experimental setup difference, it may be concluded that the use of this adsorption onto micro-sized iron oxyhydroxides followed by membrane separation might be an efficient solution for treatment of high arsenic content waters, as found in many countries including India, Bangladesh, Pakistan, Nepal, 
and China. This is because, at higher concentration driving force, the achieved $\mathrm{Q}_{10}$ values of the both applied adsorbents have been increased significantly.

Other types of fixed-bed filter that used low-cost sand coated with iron oxide to remove arsenic from groundwater, (Callegari et al. 2018), reported As(V) removal efficiency up to $99 \%$. The iron oxide-coated sand fixed-bed filter could safely treat about $2-2.25 \mathrm{~L}$ water/L filter volume until $10 \mu \mathrm{g} / \mathrm{L}$ in the effluent was reached. With this volume of product water treated, the corresponding $\mathrm{Q}_{10}$ value of the iron oxide-coated sand is $0.002 \mu \mathrm{g} / \mathrm{mg}$, which is at least three orders of magnitudes lower than the SMAHS using microsized iron oxyhydroxides in a complex water matrix. Additionally, the fixed-bed filter packed with iron oxidecoated sand needs around $2.5 \mathrm{~h}$ to reach stable arsenic effluent concentration (below $10 \mu \mathrm{g} / \mathrm{L}$ ), from a 1000- $\mu \mathrm{g}$ As $(\mathrm{V}) / \mathrm{L}$ initial concentration. However, in a SMAHS using low-cost micro-sized iron oxyhydroxides, the arsenic permeate concentration immediately reached arsenic concentrations below the drinking water guideline value starting from a $380-\mu \mathrm{g}$ $\mathrm{As}(\mathrm{V}) / \mathrm{L}$ initial concentration. Moreover, the fined-sized adsorbent can be used in a SMAHS in addition to simultaneous removal of colloids, microorganisms, and suspended solids. Furthermore, the examined hybrid system is a relatively simple, effective option to treat arsenic-contaminated water and can find its application in decentralized water treatment system. Structural costs of the hybrid system are quite low, and the energy demand of pumps is relatively low that could be provided by solar photovoltaic panels.

The SMAHS performance can also be compared with similar studies using very advanced nanomaterials to achieve As $(\mathrm{V})$ removal. The study of Bolisetty et al. (2017) shows that amyloid-carbon hybrid membranes containing 10\% (by weight) amyloid fibrils indeed diminished the $\mathrm{As}(\mathrm{V})$ concentration in ultrapure water within the drinking water guideline value, but the adsorption capacity is only $0.27 \mu \mathrm{g} / \mathrm{mg}$ for $\mathrm{As}(\mathrm{V})$, and thus is almost 3 times lower than that of $\mu \mathrm{GFH}$ and $\mu$ TMF in SMAHS, even without the presence of competing ions, showing that in the hybrid treatment system proposed in this study, the critical factor for optimized performance is the iron-based materials.

Considering environmental sustainability of process, spent adsorbent might be regenerated using an integrated procedure proposed by Tresintsi et al. (2014a). They have employed lowcost $\mathrm{MgO}$ to regenerate the used iron oxyhydroxides during $\mathrm{As}(\mathrm{V})$ removal in a fixed-bed adsorption filter. This approach combines the $\mathrm{As}(\mathrm{V})$ leaching (leaching step) and adsorption of leached $\mathrm{As}(\mathrm{V})$ onto $\mathrm{MgO}$ (adsorption step) under strong alkaline environment $(0.05 \mathrm{~N} \mathrm{NaOH})$ in a continuous recirculation configuration. The $\mathrm{MgO}$ (below $3 \mathrm{wt} \%$ ) is generally used in clinker which is a major constituent of cement. Arseniccontained $\mathrm{MgO}$ can be successfully incorporated in commercially concrete products without any secondary pollution.
Therefore, it can be concluded that the examined hybrid treatment system can be used without potential health risk in the process of waste handling.

\section{Conclusions}

Two low-cost micro-sized iron-based oxyhydroxides were proved to be efficient in removing $\mathrm{As}(\mathrm{V})$ from artificial groundwater. The second-order adsorption kinetic described the adsorption kinetic data of both media well and confirms that $\mathrm{As}(\mathrm{V})$ adsorption kinetic was faster with $\mu \mathrm{TMF}$ than with $\mu \mathrm{GFH}$ under the same experimental conditions.

The SMAHS tests showed that both adsorbents can be applied by this approach without considerable fouling of MF membrane. Like batch adsorption tests, the adsorption kinetics of $\mathrm{As}(\mathrm{V})$ onto $\mu \mathrm{TMF}$ was faster than that of $\mu \mathrm{GFH}$ in hybrid system. Within the given SMAHS setup air bubbling rate of $\geq 2 \mathrm{~L}_{\text {air }} /\left(\mathrm{min} . \mathrm{L}_{\text {slurry }}\right)$ ) was necessary to reach optimal conditions for the required mass transfer of $\mathrm{As}(\mathrm{V})$. Based on the continuous flow tests, the hybrid system benefits from a higher adsorbent dosage. The higher residence time of $5.6 \mathrm{~h}$ in the slurry reactor was favored for $\mathrm{As}(\mathrm{V})$ removal from contaminated water. As(V) adsorbent capacity in the hybrid system for $\mathrm{As}(\mathrm{V})$ increased and got almost double when the $\mathrm{As}(\mathrm{V})$ feed concentration increased to $380 \mu \mathrm{g} / \mathrm{L}$ from $190 \mu \mathrm{g} / \mathrm{L}$ at smaller hydraulic retention time. The $\mathrm{Q}_{10}$ value of hybrid system and fixed-bed adsorption filters were in similar ranges, taken into consideration the complete difference in the two compared units.

The media cost was estimated to be as low as $0.30 € / \mathrm{L}$ of treated water and media cost can be decreased significantly if $\mathrm{pH}$ of the raw water is lower than in the present study, i.e., between 6.5 and 7.5. Additionally, the media cost can be reduced remarkably by reusing spent iron oxyhydroxides, which can contribute to the low treatment cost of this hybrid system. In future research, the objective is the development of mathematical models to predict the As $(\mathrm{V})$ permeate concentration profiles in a continuous flow hybrid system.

Acknowledgments Open Access funding provided by Projekt DEAL. The authors are grateful to the Higher Education Commission (HEC) of Pakistan, German Academic Exchange Service (DAAD), and the Technische Universität Hamburg. The authors gratefully acknowledge Manassis Mitrakas, Department of Chemical Engineering, Aristotle University of Thessaloniki, Greece, for delivering tetravalent manganese feroxyhyte media. We acknowledge support for the Open Access fees by Hamburg University of Technology (TUHH) in the funding programme Open Access Publishing.

\section{Compliance with ethical standards}

Conflict of interest The authors declare that they have no conflict of interest. 
Open Access This article is licensed under a Creative Commons Attribution 4.0 International License, which permits use, sharing, adaptation, distribution and reproduction in any medium or format, as long as you give appropriate credit to the original author(s) and the source, provide a link to the Creative Commons licence, and indicate if changes were made. The images or other third party material in this article are included in the article's Creative Commons licence, unless indicated otherwise in a credit line to the material. If material is not included in the article's Creative Commons licence and your intended use is not permitted by statutory regulation or exceeds the permitted use, you will need to obtain permission directly from the copyright holder. To view a copy of this licence, visit http://creativecommons.org/licenses/by/4.0/.

\section{References}

Abejón R, Garea A (2015) A bibliometric analysis of research on arsenic in drinking water during the 1992-2012 period. An outlook to treatment alternatives for arsenic removal. Journal of Water Process Engineering 6:105-119

Adham SS, Snoeyink VL, Clark MM, Anselme C (1993) Predicting and verifying TOC removal by PAC in Pilot-Scale UF Systems. Journal - American Water Works Association 85(12):58-68. https://doi.org/ 10.1002/j.1551-8833.1993.tb06119.x

Amy G, Chen H-W, Drizo A, von Gunten U (2005) Adsorbent treatment technologies for arsenic removal

AWWARF A (1993) Research Foundation. NOM adsorption onto iron oxide-coated sand, AWWA, Denver, Colorodo

Badruzzaman M, Westerhoff P, Knappe DRU (2004) Intraparticle diffusion and adsorption of arsenate onto granular ferric hydroxide (GFH). Water Res 38(18):4002-4012. https://doi.org/10.1016/j. watres.2004.07.007

Banerjee K, Amy GL, Prevost M, Nour S, Jekel M, Gallagher PM, Blumenschein CD (2008) Kinetic and thermodynamic aspects of adsorption of arsenic onto granular ferric hydroxide (GFH). Water Res 42(13):3371-3378. https://doi.org/10.1016/j.watres.2008.04. 019

Bolisetty S, Reinhold N, Zeder C, Orozco MN, Mezzenga R (2017) Efficient purification of arsenic-contaminated water using amyloid-carbon hybrid membranes. Chem Commun 53(42):5714 5717

Bower NW (1992) Principles of instrumental analysis. 4th edition (Skoog, D. A.; Leary, J. J.). J. Chem. Educ. 69(8): A224. doi: https://doi.org/10.1021/ed069pA224.1

Callegari A, Ferronato N, Rada EC, Capodaglio AG, Torretta V (2018) Assessment of arsenic removal efficiency by an iron oxide-coated sand filter process. Environ Sci Pollut Res 25(26):26135-26143

Campos C, Marinas BJ, Snoeyink VL, Baudin I, Lainé JM (2000) PACmembrane filtration process. II Model application Journal of environmental engineering 126(2):104-111

Chang S, Waite TD, Fane AG (2003) Optimization of combined PAC adsorption-submerged membrane system for organics removal. In: Proceedings of Fifth International Membrane Science and Technology Conference, Sydney, Australia

Choi B-B, Choi Y-J, Choi J-S, Lee S, Oh H-J (2009) Energy management in submerged microfiltration systems by optimum control of aeration. Desalination 247(1-3):233-238. https://doi.org/10.1016/j. desal.2008.12.027

Drouiche M, Lounici H, Belhocine D, Grib H, Piron D, Mameri N (2001) Economic study of the treatment of surface water by small ultrafiltration units. Water SA 27(2):199-204

Essington ME (2015) Soil and water chemistry. An integrative approach. $\mathrm{CRC}$ press

Hashlamon A, Mohammad AW, Ahmad A (2017) The effect of wastewater pretreatment on nanofiltration membrane performance. $\mathrm{J}$
Water Reuse Desalination 7(1):45-52. https://doi.org/10.2166/wrd. 2016.083

Hilbrandt I, Ruhl A, Jekel M (2018) Conditioning fixed-bed filters with fine fractions of granulated Iron hydroxide $(\mu \mathrm{GFH})$. Water 10(10): 1324. https://doi.org/10.3390/w10101324

Hilbrandt I, Shemer H, Ruhl AS, Semiat R, Jekel M (2019) Comparing fine particulate iron hydroxide adsorbents for the removal of phosphate in a hybrid adsorption/ultrafiltration system. Sep Purif Technol 221:23-28. https://doi.org/10.1016/j.seppur.2019.03.044

JIA Y, WANG R, FANE A (2005) Atrazine adsorption from aqueous solution using powdered activated carbon - improved mass transfer by air bubbling agitation. Chem Eng J. https://doi.org/10.1016/j.cej. 2005.10 .014

Jia Y, Wang R, Fane AG (2009) Hybrid PAC-submerged membrane system for trace organics removal. Chem Eng J 155(1-2):155160. https://doi.org/10.1016/j.cej.2009.07.032

Kalaruban M, Loganathan P, Kandasamy J, Vigneswaran S (2018) Submerged membrane adsorption hybrid system using four adsorbents to remove nitrate from water. Environ Sci Pollut Res Int 25(21):20328-20335. https://doi.org/10.1007/s11356-017-8905-9

KATSOYIANNIS I, ZOUBOULIS A (2002) Removal of arsenic from contaminated water sources by sorption onto iron-oxide-coated polymeric materials. Water Res 36(20):5141-5155. https://doi.org/ 10.1016/s0043-1354(02)00236-1

Katsoyiannis IA, Zouboulis AI, Mitrakas M, Althoff HW, Bartel H, others (2013) A hybrid system incorporating a pipe reactor and microfiltration for biological iron, manganese and arsenic removal from anaerobic groundwater. Fresenius Environ Bull 22(12c):3848 3853

Katsoyiannis IA, Mitrakas M, Zouboulis AI (2015a) Arsenic occurrence in Europe. Emphasis in Greece and description of the applied fullscale treatment plants. Desalin Water Treat 54(8):2100-2107. https://doi.org/10.1080/19443994.2014.933630

Katsoyiannis IA, Voegelin A, Zouboulis AI, Hug SJ (2015b) Enhanced As (III) oxidation and removal by combined use of zero valent iron and hydrogen peroxide in aerated waters at neutral $\mathrm{pH}$ values. $\mathrm{J}$ Hazard Mater 297:1-7. https://doi.org/10.1016/j.jhazmat.2015.04. 038

Lebeau T, Lelièvre C, Buisson H, Cléret D, van de Venter LW, Côté P (1998) Immersed membrane filtration for the production of drinking water. Combination with PAC for NOM and SOCs removal. Desalination 117(1-3):219-231. https://doi.org/10.1016/S00119164(98)00101-5

Qu F, Yan Z, Wang $\mathrm{H}$, Wang $\mathrm{X}$, Liang $\mathrm{H}, \mathrm{Yu} \mathrm{H}, \mathrm{He} \mathrm{J}, \mathrm{Li} \mathrm{G}$ (2018) A pilot study of hybrid biological activated carbon (BAC) filtration-ultrafiltration process for water supply in rural areas. Role of BAC pretreatment in alleviating membrane fouling. Environ Sci: Water Res Technol 4(2):315-324. https://doi.org/10.1039/c7ew00381a

Simeonidis K, Papadopoulou V, Tresintsi S, Kokkinos E, Katsoyiannis I, Zouboulis A, Mitrakas M (2017) Efficiency of iron-based oxy-hydroxides in removing antimony from groundwater to levels below the drinking water regulation limits. Sustainability 9(2):238. https:// doi.org/10.3390/su9020238

Sinha S, Lee N, Amy G (2002) Innovative technologies for arsenic removal. In: Water Quality and Treatment Conference. Seattle, WA

Stylianou S, Simeonidis K, Mitrakas M, Zouboulis A, Ernst M, Katsoyiannis IA (2018) Reductive precipitation and removal of $\mathrm{Cr}$ (VI) from groundwaters by pipe flocculation-microfiltration. Environ Sci Pollut Res Int 25(13):12256-12262. https://doi.org/10. 1007/s11356-017-9967-4

Thirunavukkarasu OS, Viraraghavan T, Subramanian KS (2003) Arsenic removal from drinking water using granular ferric hydroxide. WSA 29(2). https://doi.org/10.4314/wsa.v29i2.4851

Tresintsi S, Simeonidis K, Vourlias G, Stavropoulos G, Mitrakas M (2012) Kilogram-scale synthesis of iron oxy-hydroxides with 
improved arsenic removal capacity. Study of Fe (II) oxidationprecipitation parameters. Water Res 46(16):5255-5267. https://doi. org/10.1016/j.watres.2012.06.049

Tresintsi S, Simeonidis K, Estradé S, Martinez-Boubeta C, Vourlias G, Pinakidou F, Katsikini M, Paloura EC, Stavropoulos G, Mitrakas M (2013a) Tetravalent manganese feroxyhyte. A novel nanoadsorbent equally selective for As (III) and $\mathrm{As}(\mathrm{V})$ removal from drinking water. Environmental science \& technology 47(17):9699-9705. https:// doi.org/10.1021/es4009932

Tresintsi S, Simeonidis K, Zouboulis A, Mitrakas M (2013b) Comparative study of $\mathrm{As}(\mathrm{V})$ removal by ferric coagulation and oxy-hydroxides adsorption. Laboratory and full-scale case studies. Desalin Water Treat 51(13-15):2872-2880. https://doi.org/10.1080/ 19443994.2012.748011

Tresintsi S, Simeonidis K, Katsikini M, Paloura EC, Bantsis G, Mitrakas M (2014a) A novel approach for arsenic adsorbents regeneration using MgO. J Hazard Mater 265:217-225. https://doi.org/10.1016/ j.jhazmat.2013.12.003

Tresintsi S, Simeonidis K, Mitrakas M (2014b) Mn-feroxyhyte. The role of synthesis conditions on As (III) and As(V) removal capacity. Chem Eng J 251:192-198. https://doi.org/10.1016/j.cej.2014.04. 033
Usman M, Katsoyiannis I, Mitrakas M, Zouboulis A, Ernst M (2018) Performance evaluation of small sized powdered ferric hydroxide as arsenic adsorbent. Water 10(7):957. https://doi.org/10.3390/ w10070957

Vieira BRC, Pintor AMA, Boaventura RAR, Botelho CMS, Santos SCR (2017) Arsenic removal from water using iron-coated seaweeds. J Environ Manag 192:224-233. https://doi.org/10.1016/j.jenvman. 2017.01.054

Vigneswaran S, Chaudhary DS, Ngo HH, Shim WG, Moon H (2003) Application of a PAC-membrane hybrid system for removal of organics from secondary sewage effluent. Experiments and modelling. Sep Sci Technol 38(10):2183-2199

Violante A, Ricciardella M, Del Gaudio S, Pigna M (2006) Coprecipitation of arsenate with metal oxides. Nature, mineralogy, and reactivity of aluminum precipitates. Environmental science \& technology 40(16):4961-4967

Westerhoff P, Highfield D, Badruzzaman M, Yoon Y (2005) Rapid small-scale column tests for arsenate removal in iron oxide packed bed columns. J Environ Eng 131(2):262-271

Publisher's note Springer Nature remains neutral with regard to jurisdictional claims in published maps and institutional affiliations. 